\title{
Performing (for) Populist Politics
}

\section{Music at the Nexus of Egyptian Pop Culture and Politics}

\author{
Joel W. Abdelmoez \\ University of Cambridge, Cambridge, UK \\ jw.abdelmoez@cantab.net
}

\begin{abstract}
In July 2013, after months of protest, Egypt's first democratically elected president, Mohammed Morsi, was ousted by the Egyptian armed forces. The Muslim Brotherhood, who supported Morsi, took to the streets, chanting and singing against the ousting, which they termed a military coup, while supporters of Sisi, who viewed it as a revolution, began producing songs to show their allegiance to the military leadership. While abundant research has been conducted on the role of oppositional and revolutionary music in Egypt since 2011, relatively little has been done on the widely popular promilitary music sometimes known as watani music. Watani songs are a genre of patriotic music made by popular artists to show their allegiance to the Egyptian armed forces. In this paper I examine the surge of watani songs and trace their history back to the Nasser era, thereby showing a continuity in style as well as content. I further argue that there are connections between nationalism and gender constructions, as the national project comes with obligations for men to offer their bodies to the cause. This obligation is aided by constructions about 'male bravery' and 'courage' that are designed to make men believe that military service is somehow essential to masculinity. Watani music, whether commissioned or not, fits well with this mythology of military men. It forms an ideological undercurrent, supports the narrative that it is necessary for patriotic military men to bravely safeguard the nation against its enemies.
\end{abstract}

\section{Keywords}

Egypt - popular culture - performance - masculinities - music - gender 


\section{Introduction}

Watani songs - a reference to the Arabic word for homeland, watan - is a genre of patriotic music made by popular artists to show their allegiance to the Egyptian state and armed forces. These songs are largely associated with the Nasser era; the most famous example is the song 'al-Watan al-akbar' (The great homeland) from 1960, although similar songs were also commissioned by former president Hosni Mubarak in the 199os and have enjoyed a surge in popularity since the accession to power of Abdel Fattah El-Sisi in 2014. ${ }^{\text {T The songs often }}$ revolve around concepts of peace and national unity, and commonly praise martyrs, particularly those from the military and police forces. Many of the music videos of contemporary watani songs have a strong military theme and use footage of the armed forces in action. In this paper I provide an overview of these songs and their accompanying videos and I examine what their resurgence tells us about cultural politics in Sisi's Egypt, particularly in relation to the role of the military in Egyptian popular culture. Furthermore, in the present study I unpack the gendered aspects of these songs and accompanying music videos by showing how watani music promotes militarized masculinity and perpetuates an entanglement between militarism and idealized masculinities.

\section{$2 \quad$ 'Bless These Hands'}

Watani songs have enjoyed mass popularity, especially since the 2013 ousting of Islamist president, Mohamed Morsi, and the return of a military officer, former field marshal Abdel Fattah El-Sisi, to the presidency in 2014. One of the most popular songs in support of the new military regime is the song "Teslam al-ayadi' (2013), meaning 'May the hands be safe', or idiomatically 'Bless these hands.'2

The song has become larger than life. To the majority of Egyptians, it became the synonym of 'salvation', 'resuscitation', 'ending of a nightmare', 'restoring a stolen nation', 'twist of fate', and last but not least 'Defense Minister Field Marshall Abdel Fattah El Sisi a charisma that has been lost for decades and found at last.'

KHAIRY 2014

1 'Al-Watan al-akbar' was televised in 196o: https://youtu.be/1pPJao7cOKk.

2 'Teslam al-ayadi' and its official music video is available online: https://youtu.be/fih2vjM7 Uho. 
'Teslam al-ayadi' begins with rhythmically spoken words that translate to 'this is the hero who sacrificed his life', while the video shows a line of black-clad soldiers walking toward the camera, filmed from below. This is quickly followed by a short clip of (then field marshal) Sisi in military clothes talking to a group of soldiers, with an Egyptian flag fluttering and flashing throughout the clip. It is a befitting opening, clearly intended to praise military masculinity. The military theme continues throughout the music video, mixed with scenes from the recording studio, showing the artists - which is important, as they are all popular artists, openly showing their support—-singing, dancing and waving the Egyptian flag.

The composition and lyrics are by the artist Mostafa Kamel—although there is some controversy as to whether or not the melody was stolen - and is sung by Kamel, with an ensemble of popular artists, such as Hakim, Hisham Abbas, Khaled Aggag, Ghada Ragab, Suma and Ehab Tawfik. Mostafa Kamel became famous in the late 1980s and 199os mainly producing so-called sha'bi music. Although 'Teslam al-ayadi' is not quite an example of sha'bi music (it is described by Kamel as an operetta) it is of interest that the song was written and performed by an artist that is associated with this genre, since he was likely commissioned to write the song precisely because he was popular with a certain audience. Sha'bi (lit., 'popular' or 'of the people', sha' $b$ ) songs are typically associated with working-class Egyptian neighborhoods; Swedenburg describes this genre as below:

\begin{abstract}
About one half of Cairo's population lives in 'ashwa'iyyat, 'haphazard', unplanned settlements that teem with the poor, working and lower middle classes. Sha'bi music, rooted in the 'ashwa'iyyat as well as the traditional popular quarters of Cairo, has long been derided as unsophisticated at best by Egypt's educated elites. But many educated Egyptians listen to and appreciate sha'bi music, if apologetically, and so several sha' $b i$ artists have crossed over to mainstream culture, to wit, Sha'ban 'Abd al-Rahim, Hakim and Ahmad 'Adawiyya.
\end{abstract}

SWEDENBURG 2O12: 42

The featured singers are a mix of sha'bi and so-called shababi singers. Shababi is a form of Arab pop that started in the 1970s and grew more popular in the 1980s and 199os, influenced by American and European pop groups; it is a fusion of western music styles, such as disco, rock or jazz, with 'Arab music characteristics (Arabic language, lyrical meanings, or rhythms)' (Grippo 2010: 143). The term shababi refers to young people, and was originally seen as music for the youth, although Grippo points out that by the 199os, shababi was the main- 
stream form of Egyptian pop. Hisham Abbas is known as a shababi singer, while Hakim, who is also mentioned in the quote by Swedenburg, is closely associated with the sha'bi style. Mostafa Kamel's background is similar to that of Hakim; he makes music 'for the masses'. He produced 'Teslam al-ayadi', which immediately became enormously popular, and after its release could be heard throughout Cairo, not just in the 'ashwa'iyyat. Anastasia Valassopoulos and Dalia Mostafa write that ' $[\mathrm{a}] \mathrm{lthough}$ the patriotic militaristic discourse appears to dominate media channels and political debates in Egypt, recent developments on the cultural scene indicate that the voice of the 2011 revolution is still alive and well' (Valassopoulos and Mostafa 2014: 640). Indeed, there are alternative, revolutionary and counter-cultural movements in Egypt, despite repression by the military regime, but the popularity and unique position of 'patriotic militaristic discourse' in the Egyptian music scene is undeniable, and 'Teslam al-ayadi' is a clear example of this. Similarly, the popularity of Kamel and his cohorts, both inside and outside the 'ashwa'iyyat, shows the permeation of the genre, which cuts through social strata and the artificial dichotomy of 'high and low' culture.

'Al-Watan al-akbar' is perhaps the most well-known watani song and one of the earliest examples of the genre. The song was commissioned by the Egyptian government to celebrate the laying of the first stone of the Aswan Dam (Gordon and Arafa 2014). The melody was written by the famous composer Mohammed Abdel-Wahhab, who also did the arrangement; the lyrics were written by the nationalist poet Ahmad Shafik Kamal. The performance included several famous Arab singers, not just from Egypt: Abdel-Halim Hafez, Fayda Kamel, Nagat El-Saghira, Shadia, Warda and Sabah. Combining the stardom and popularity of these artists, the ensemble itself worked to consolidate the idea, promoted by Nasser, of a unified pan-Arab nation.

The Nasser era, during which watani songs proliferated and enjoyed massive popularity in Egyptian society, was a period marked by pan-Arabism as well as nationalism and, indeed, nationalization. The grand orchestrations, with lyrics praising the Arab nation and sung by popular Arab stars, fit well with nationalist mythology. Nasser, who was close to many of the most popular musicians of the time, likely understood the importance of popular culture in garnering support. He was also a supporter of radio and television, and is believed to have backed the founding of the first overtly pan-Arab radio station, Voice of the Arabs, which was launched in 1953 and quickly became known for its use of 
nationalistic music and anti-colonial rhetoric; he was also known to support popular singers like Umm Kulthum (Boyd 1975). Nasser's support for radio also meant an increase in broadcasting hours; this provided more opportunity for Egyptian musicians to share their work throughout the Arab world, and thus it facilitated the increased popularity of music that catered to a wider Arab audience (Frishkopf 2010).

When the first Egyptian television network was launched in 196o, the popularity of pan-Arab music carried over from radio. 'Al-Watan al-akbar' was first aired on national television in 196o, performed by the then brand-new Egyptian TV orchestra, which was led by conductor Rif'at Garana, although this particular song was conducted by the composer himself (Nassar 2010). The televised performance began with a short introduction and title screen with the names of the people involved in the production. On the left side of the title screen was a collage of flags (or more accurately tapering pennons) of several Arab countries. This was followed by a shot of Abdel-Wahhab in front of the orchestra and choir; it then cuts to a drumline playing a marching percussion intro, leading to two rows of men in suits marching in while singing along to the melody. They march up a ramp, while two rows of women march with flags of the Arab countries, as in an Olympic parade of nations. As stated by McDonald: 'Two large uniformed choruses (one male and the other female) supplemented the orchestra and provided an iconic sign of 'the Arab masses' singing together in solidarity' (McDonald 2013: 73).

After marching in place and vocalizing along to the melody, the marchers began descending from the ramp, again while singing the opening chorus:

Watani habibi al-watan al-akbar [My dear homeland, the greatest nation.]

Yawm wara' yawm amgaduh btikbar [Day after day, its glory multiplies]

Wa-intisaratuh maliya hayatuh [Triumphs are its lifeblood]

Watani byikbar wa-byitharrar [My homeland grows larger and becomes free]

Watani, watani [My homeland, my homeland!]

The lyrics extol the nation, and each verse, sung by a different Arab star, mentions different countries and places, such as Marrakesh, Bahrain, Damascus and Jeddah. This further strengthens the message that the Arab people are united.

Gordon and Arafa note that the popularity of watani music waned during the presidency of Sadat, perhaps because of the decline of pan-Arabism during that era, but that it began to return under Mubarak: 'Many of these tunes disappeared from the airwaves during Anwar al-Sadat's rule, but they came back, 
punctuated by the spread of cassette technology, in the early 1980s' (Gordon and Arafa 2014: 36). This seems to imply both an ideological explanation (a decrease in the appeal of the mythology in the wake of Nasser's death and the loss of the Six Day War) and a technological explanation (a resurgence in new media technologies).

\section{$4 \quad$ 'We Chose Him'}

Perhaps the most well-known watani song of the Mubarak era is 'Ikhtarnah', meaning 'we chose him'. This is a direct reference to Hosni Mubarak and echoes the lyrics of a watani song from 1956, entitled 'Ihna al-sha'b' (i.e., 'we are the people'). 'Ikhtarnah' was performed in a live televised performance in conjunction with the 1999 presidential confirmation referendum in which the candidate appointed by parliament (the incumbent Mubarak) won the electorate's approval with 94 percent of the votes. Note that no other candidates were allowed to enter the race and strictly speaking, it was not an election, but a referendum. El Hamamsy and Soliman (2013) argue that this song and its broadcasting was a way of ensuring the people's sense of 'choosing' Mubarak, despite the fact that they merely 'approved' what was already decided. At that point in time, there had not been a multi-party, multi-candidate election under Mubarak's rule, and even his initial ascension to the presidency had come not through an election, but as a result of the assassination of the previous president, Anwar Sadat. As such, it would be an overstatement to say that Mubarak was 'chosen' by the Egyptian people.

The artists, who were all popular at the time, were commissioned by Safwat al-Sherif, the then minister of information. The song shows how popular music has been used as a mode of governance in Egyptian politics, and also that the tradition of nationalistic, pro-regime songs/operettas (such as the watani songs) draw from a history of authoritarian politics, and is by no means a new phenomenon. As such, it is possible that one purpose of watani songs relates to the same principle; that the appearance of support, provided through music performed by popular artists, can garner actual support regardless of existing

3 Here 'Ikhtarnah' was performed in a live televised performance (in 1999) with Mubarak and his wife Suzanne in the audience, see https://youtu.be/8PD3pgvExvo. 'Ihna el-sha'b' is available online: https://www.youtube.com/watch? $v=r F g J b R-p f S 4$. 'Ikhtarnah' was also parodied on El-Bernameg, a well-known TV show with comedian Bassem Youssef, in which the lyrics were changed to 'we chose him, now we're stuck', in reference to the election of Mohamed Morsi. The performance is available online: https://youtu.be/UhCUSQ1crno. 
support. At the same time, they are jingoistic homages to al-watan, aimed at consolidating a form of patriotism that is closely connected to the idea of a father/president (cf. Kabesh 2015; Baron 2005).

\section{5}

'Go Down!'

Other songs are not as blunt as 'Teslam al-ayadi' in their references to the military but can still be considered pro-military, nationalistic or patriotic songs, if not watani songs. One example of this is 'Enzel' (Go down) by Bahaa Sultan and Touba, which was released shortly before Mohamed Morsi was deposed, as an attempt to get people to go down to the streets and squares and protest. ${ }^{4}$ Unlike previous songs detailed in this essay, this was a private initiative, not a direct product of the state. Nevertheless, it shares many features with the statesponsored watani songs and could be regarded as a private sector response to the watani trend.

The song features a choir of people, which is typical for watani songs, all dressed so as to represent a diversity of 'regular people'-one man is wearing a hardhat, one woman wears pearls and the one next to her wears a veil, there is a young man in a T-shirt and an older man in a galabeyya. All of them give a military salute and sing in chorus to the rhythm of a military march; they are backed by a percussion drum line, another common feature of watani music.

Both 'Enzel' and 'Teslam al-ayadi' follow a simple structure that repeats the title-also a prominent feature of 'Ikhtarnah' (We chose him) — this ensures that the message is clear and that it is easy to communicate because it is easy to memorize. The verses are short, making the refrain (that often just consists of a repetition of the title) appear frequently, pounding out the message, whether that is teslam al-ayadi, teslam ya gesh biladi (bless these hands, bless my country's military) or 'ikhtarnah, ikhtarnah' ('we chose him, we chose him').

'Six Hours'

Many watani songs feature a religious theme, such as praising God for the strength of 'our military', possibly as a way of invoking a feeling of national unity - even though it is often also emphasized that Egypt, and the Egyptian army, consists of both Muslims and Christians (although there is never any

4 The music video is available online: https://youtu.be/8R5A-H3DrtA. 
mention of Jews, atheists, Baha'i, or any other religious group). Particularly noticeable is the religious theme in Ehab Tawfik's 'Set sa'at' (Six hours), in which almost every line begins with the phrase 'Allahu akbar' (God is great) followed by sentiments on the 'unbreakable' nature of the Egyptian nation, its deep history and praise of its army's martyrs. ${ }^{5}$ For example, the first line of 'Set sa'at' is 'God is great, who can break a nation that liberated its land in just six hours?'a reference to the crossing of the Bar Lev Line, in the October War 1973, when the Egyptian military took back Sinai from Israel.

Ehab Tawfik, who is a well-known shababi singer, was also one of the performers participating in 'Teslam al-ayadi'. 'Set sa'at' was also produced shortly after the ousting of Morsi and was clearly meant as Tawfik's stamp of approval for the military and Sisi. The music video showcases both scenes of the Egyptian armed forces in action and shots of field marshal Sisi, similar to 'Teslam al-ayadi', but it also includes scenes of violence by alleged supporters of Morsi. This is shown as a way to make clear the 'necessity' and justification for military intervention. This is a common theme for several pro-military music videos; it builds on the idea that the military brings security and stability. To publicize his support for the military, Tawfik gave Egyptian television channels permission to broadcast the song free-something that many others jumped on the opportunity to do (albawaba 2013).

Gilman writes that 'connections between music and politics in Egypt are both long-standing and deep' (Gilman 2014: 2). However, in the context of Egypt, research on music and cultural politics in recent years has mainly focused on protest music and oppositional movements (cf. Swedenburg 2012; Valassopoulos and Mostafa 2014; Sprengel 2019). ${ }^{6}$ This comes as no surprise, considering the deep impact of the events of 2011 and the following years of political turmoil, not least on the cultural scene, and the impact of cultural phenomena and developments on these same events. However, Mark LeVine acknowledges this shift toward pro-regime music in Egypt, stating that by mid-2013 the protest songs had been 'replaced by the counter-revolutionary pop hit "Teslam Ayadi" (Bless Your Hands), a hyper-melodramatic, chauvinistic tribute to the military

5 The music video is available online: https://youtu.be/Q6BPjNMXIT8.

6 One notable exception is Daniel Gilman's work, Cairo Pop: Youth Music in Contemporary Egypt (Minneapolis: University of Minnesota Press, 2014), which focuses largely on youth and popular music. 
and the Egyptian state sung by 199os-era star who were close to the Mubarak regime' (LeVine 2015: 1289). Nevertheless, it is true that songs and music played an integral part in the protests and uprising that led to Mubarak's downfall.

El Hamamsy and Soliman argue that Tahrir square, as a scene for the performance of politics as well as music, broke the 'artist-audience setup', thus blurring the separation of those producing the music and those 'consuming' it (El Hamamsy and Soliman 2013). Furthermore, they note that ' $[t]$ his was also one of the very few times when art represented and celebrated living people and not an abstract concept, be it a nation, a president, or a victory' (El Hamamsy and Soliman 2013: 251). However, 'living people' is itself an abstract concept; certainly all sides in the revolution claimed to represent living people? What is clear, and what made music so important to the protests in 2011 (as with earlier protests as well), was its ability to create and maintain revolutionary momentum, a political-collective effervescence, which may have aided the music's ability to unite diverse populations. The genre of watani music, then, may be understood, at least in part, as drawing from protest music, or, perhaps, appropriating the unifying momentum of that genre, considering the popularity of watani music that similarly defied social stratifications. Indeed, it is worth noting that many of the songs sung during the 2011 protests also shared the nationalist theme and lyrical style of watani songs (especially of the older variety, such as 'al-Watan al-akbar'). Most noteworthy are the songs of Sayyid Darwish, which were frequently sung in Tahrir square during the eighteen days of protest. Swedenburg points out: 'Among Darwish's most memorable nationalist compositions are "Um Ya Masri” (Rise O Egyptian) and 'Biladi, Biladi' (My Country, My Country), which became Egypt's national anthem' (Swedenburg 2012: 40).

There have of course been watani songs prior to the ousting of Morsi in 2013. Indeed, parallel to the protest songs of 2011, songs were performed in support of Mubarak, and songs praised the military, which then backed the president. For example, Amr Mostafa lent his creative production to support Mubarak. Another - in my eyes more interesting - example is Tamer Hosny, who was known as a soft and romantic artiste-type prior to the revolution and was accused of avoiding the mandatory military service. Possibly coerced by the military, or perhaps in an attempt to salvage his image, Hosny began performing pro-military songs during the time of the uprising and from as early as 8 January 2011 he promoted the term 'id wahda', meaning 'one hand'? This is

7 Hosny uploaded the song 'Id wahda' to his YouTube channel on 8 January 2011: https://youtu .be/MCw7vQXEAtI. 
significant because the term, which is a part of the phrase 'al-gesh wa-l-sha' $b$ id wahda' (i.e., 'the army and the people are one hand') was often chanted in revolutionary demonstrations after the army turned against Mubarak, but before anti-military sentiment returned to the revolutionary ranks. Hosny used it a little differently though; while still praising the military, singing about soldiers who sacrifice themselves for Egypt, he did not say that the people and the military are one hand, but that the hand protecting Egypt is both Muslim and Christian. Besides praising the military in 'Id wahda', Hosny also performed other songs to bridge the gap between the military and the protestors. For example, Hosny's pro-military contribution includes the song 'Motshakeren ya geshna' (lit., 'Thank you our army'). Furthermore, in an attempt to salvage his reputation with the revolutionaries, Hosny also performed a song (Shuhada) honoring the martyrs of the January 25 th revolution, and included a reference to 'rugula masriyeen' ('Egyptians' manhood') here acting as a signifier of strength, courage and resistance. In talking to friends and acquaintances in Egypt about Hosny's support for the military, he has variously been called a 'musical baltagi' (a regime-hired thug), or a 'puppet of the military'. He remains an ambivalent figure on the Egyptian music scene. ${ }^{8}$

Gilman notes, in defense of studying music, that-no matter the variety or genre-it has the ability of 'moving listeners by playing on their emotions on a mass-media scale, and thereby inspiring them to commit one act or another' (Gilman 2014: 2). This description adheres well to the intended purpose of watani music - to inspire support for the military regime by playing on and evoking the nationalistic emotions of its listeners. Just as music can be, and has been, used against the military, it can also be used for it. Furthermore, music not only carries messages and meanings in relation to overtly political issues on the national scale, but also bears subtler issues, such as gender politics. While many songs, such as Tamer Hosny's 'Si al-Sayed' (2013) which evokes and celebrates the authoritarian patriarchal character of Mr. alSayed (from the Cairo Trilogy novels by Naguib Mahfouz) carry 'lessons' about gender performance, they often become particularly pronounced when combined with a pro-military theme. Songs that praise the military often invoke

8 Hosny's support for Mubarak, as well as that of his fellow artist Amr Diab, is detailed here (in Arabic): http://shorturl.at/uMPRT. The chant also occurred later, when the army began dispersing protesters in Tahrir, as a way of evoking sympathy in the soldiers: https://youtu .be/JY2mU-Drmx8; Hosny's 'Motshakeren ya geshna' is available online: https://youtu.be/ wnGGonpioso (Hosny has now made the link to this site private; it is available, albeit in poor quality, at https://youtu.be/tFc66oIjiY4); 'Shuhada' is available online: https://youtu.be/ g9lybr99_qE. 
the rugula (manhood) of the soldiers, and accompanying music videos show military men (there is never any indication that military personnel can be read as non-male) scaling walls, marching in the streets or standing in front of fluttering flags. These songs and music videos are intended to reinforce a performance of masculinity that places value on traits that encourage men to engage in military activities. Their purpose is to instill a view that such militaristic, protective traits are a necessary part of a masculine psyche, socializing men to be 'combat-ready'. The songs, as well as other media forms, present the military as the male guardian of the (imagined) female nation, and the men who refuse to go along are ridiculed and relegated to a demasculinized position.

Masculinities and the Military

In Egypt, the army occupies a rather unique space in society, as it is the institution from which every president from $195^{2}$ to 2012 have hailed, and with the exception of the one-year stint of Mohamed Morsi, the former military officer Abdel Fattah el-Sisi now occupies the presidency. While the Egyptian armed forces declined in power and position during the Mubarak presidency, they still maintained a significant role in society, a role that was clearly demonstrated during the Arab Spring. Unsurprisingly, since the election of Sisi, they have again grown more influential; new laws have expanded their jurisdiction and role in domestic security (cf. Brown, Shahin and Stacher 2013; Abdel Kouddous 2014). Furthermore, the Egyptian army is also involved in many public projects; they build new highways and hospitals, they own factories and participate in construction work and manufacturing, to such an extent that they exclude civilian businesses that cannot compete with the benefits enjoyed by the armed forces (Morsy 2014; Abul-Magd 2013). A 2019 report also states that ' $[\mathrm{t}]$ hey have expanded into new sectors as diverse as steel production, pharmaceuticals, gold prospecting, and managing religious endowments and pilgrimage' (Sayigh 2019: 1).

Military forces are a common sight in the streets of Cairo, but their presence and new 'mission' as public defenders of morality has also caused controversy, as it is a sexualized 'securitization' that serves 'to protect, rescue, and secure certain idealized forms of humanity identified with a particular family of sexuality, morality, and class subjects' (Amar 2013: 6). By adopting a discourse, prevalent both locally and in international media and politics, that portrays workingclass Arab men as violent, predatory and dangerous to women, the security state justifies the policing and repression of those communities as necessary 
measures to protect 'our women'. This point is also noted by Grove who writes in relation to the securitization of Cairene streets under the guise of fighting harassment:

There is also Egypt's cultural acceptability of harassment as a target, which plays into culturalist explanations of sexual violence that rely on Orientalist tropes of unchecked masculine aggression and the 'predatory sexuality' of the so-called Arab street, which, as Amar ... argues, resonate with a commonly accepted presumption that Egypt needs an authoritarian government to keep its politics and population in order.

GROVE 2O15: 358

This, of course, may seem contradictory, given that the army, to a large extent, consists of working-class men, and also given the army's involvement in the harassment of women, and use of rape as a weapon against women participating in protests(Sunday Grove 2015).

Similarly, Cynthia Enloe also warns about 'securitized masculinities', and the dangers of certain discourses in studies on Arab and Muslim masculinities. The issue lies in the framing of some groups of men as thugs and deviants, and other men as necessary guardians of morality and virtue: 'anyone (locally or abroad) who accepts unquestioningly those state-serving, patriarchy-supporting, masculine constructions will unwittingly undermine the chances for real democratization' (Enloe 2013: 78). According to this perspective, it is necessary to look at the 'masculine constructions', which, as I have found, are very much promoted by the military and security branches of the state.

While studies on gender politics over the last few decades have rapidly expanded with more critical studies on men and masculinities, including many works with a focus on the Middle East and North Africa (cf. Naguib 2015; Van Eynde 2015; Rizzo (ed.) 2014; Ghannam 2013; Inhorn 2012), surprisingly little has been written about masculinities and the military. Of course, there are some exceptions, such as Higate (2003) and Ghoussoub and Sinclair-Webb (2000), but these works are by now quite outdated. In academia as well as media and popular culture, there is a severe lack of attention given to men as gendered subjects and the presence of men, even while male-coded subjects are grossly overrepresented (as in representations of the military), and when men are literally the only people represented. This makes their presence seem 'given' or natural, and therefore unquestioned. The fact that any and all discussions of the military conjure images of men, and this fact garners no attention, makes the correlation of men and soldiers appear to be a given. From this point then, there is nothing to discuss or debate; it just 'is'. 
This point is demonstrated in a study on military masculinity in Egyptian news media (Abdelmoez 2018), where it was found that the media indeed enforce a specific representation of the military as a male masculine institution in which no room is given to read the military and military personnel as anything other than male. This relates to the semiotic potential of 'military', as a signifier connoting 'masculinity', that is, it draws from previous uses to inform such a connotation. 'Military masculinity' builds on a constant correlation between 'military' and masculine figures, and of masculine figures as 'militaristic'. Therefore, this is a self-perpetuating gendering, which can only really be disrupted by a combination of radical and transgressive measures. These measures include, I believe, calling out and paying attention to the prerogatives of the security state in defining what constitutes 'good' or 'proper' masculinity (i.e., that of the national military), and what is defined as 'deviant' masculinity (i.e., working-class men, gay men and other men of marginalized orientations), all of whom often suffer systemic violence that is encouraged by mass media and perpetrated by military and police forces.

\section{Music, the Nation and the Military}

In most of the non-Western world, cultural production is an arena where various forces struggle to define national identity in ways that are more contentious than in the West. For example, the commoditization of the female body in popular culture, which in the West is often marginally discussed as a moral issue, creates major controversies in the non-Western world, where women's roles are central to historical memory and national identity.

KRAIDY 2006

The importance and impact of looking at the military and military masculinities in Egypt is arguably greater than ever before, with a (former) military officer as president, and a government that is working harder than ever to promote a specific narrative. The narrative is that of a protective father figure (the president), leading his sons (the soldiers) on a mission to rescue the nation from any and all forces of evil — whether these are Islamists, financial problems, or 'the most dangerous shemale in Egypt!' Amal Treacher Kabesh writes about the popularity of Sisi and the military narrative:

9 The story of 'the most dangerous shemale in Egypt' is an example of military and police involvement in matters of sexual morality. This refers to the arrest of a young transwoman 
Many favorable analogies are made between Al-Sisi and Nasser and both are represented as fathers of the nation. Memories of Nasser challenging Britain and winning the Suez War have been revived and provide ballast for a potent belief that Egypt will take its rightful place as the nation in the Arab world. These memories and narratives are reinforced by a massive new project to extend and widen the Suez Canal in order to increase the number and size of ships that can use it. We watched the extensive news coverage of the unveiling of these plans, and, while we knew the coverage was carefully orchestrated, we wept with relief that plans were being followed through to ensure that Egypt will be prosperous again.

KABESH 2015: 347

In this manner, music (particularly watani songs) is an important medium for putting forward this narrative; it reinforces the idea of the leader as a father of the nation and strengthens the analogies between Sisi and Nasser. Gilman writes that 'Teslam al-ayadi' is 'quite nakedly another piece of military (and soon thereafter government) propaganda' (Gilman 2014: 207). While it may be painfully obvious that this and other songs are commissioned, and that they are deliberate attempts to promote a pro-military agenda, people still consume these songs and are influenced by them, just as Kabesh recalls weeping with relief at the coverage of the expansion of the Suez Canal, despite knowing that it is just an orchestrated attempt at bolstering the military. Indeed, the oppositional and revolutionary songs that many music scholars and anthropologists favor in their work do have the ability to affect people, despite a clear agenda - in fact, a clear agenda might be a requirement for the songs to be called oppositional—but pro-military songs, however nakedly propagandistic they are, have a similar ability.

The phenomenon and popularity of watani songs has been observed and discussed by journalists, while it is largely ignored by scholars. Already in August 2013, Maha ElNabawi, writer for the independent Egyptian news site Mada Masr, noted the rise in nationalistic music and wrote: 'The most recent example of musical nationalism is the caricature-like display of military propaganda in

and how a report in Youm7, a newspaper generally known to be aligned with the military, framed the story as a matter of danger. The woman was accused of offering sexual services through her YouTube account, specifically offering 'sadistic sex'; however, it is clear that the arrest aligned with the larger crackdown on Egypt's queer communities. The article, in which the woman is referred to as 'the most dangerous shemale in Egypt' is avail-

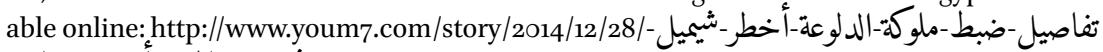
2006407\#.VKCTssDA. 
Mustafa Kamel's music video "Tislam al-Ayady" (Bless Your Hands), which was released last month' (ElNabawi 2013). In the same article, ElNabawi criticizes this song for its branding as an 'operetta'; she goes on to quote Egyptian composer Ahmed El-Hennewy, who says that 'it is very alarming that people are even calling "Tislam al-Ayady" an operetta because it most certainly is not, and this shows an utter lack of cultural education' (ElNabawi 2013). Given that the aim and purpose of the songs is to consolidate a sense of patriotism, I would argue that the term 'operetta' works as a genre, not in the sense that it reveals something about the musical style, but in that it is a sort of contract between musician and audience - knowing previous 'operettas', the audience will know what to expect in terms of the message, if not the structure. According to this view, genres are context specific and mean different things to different people. The genre tells the audience what to expect; in the Egyptian context this means that the label operetta leads the audience to expect a jingoistic song in the spirit of 'Ikhtarnah' or 'al-Watan al-akbar'. This view of 'genre' also explains El-Hennewy's strong opposition to the term; he likely does not want this type of song associated with the older anthems that he, as a composer, appreciates as operettas. This branding can also be interpreted, more simply, as a descriptor of a song performed by an ensemble of singers praising the nation. In either case, it is clear that the song is mainly referred to in this way in order to create associations with earlier watani songs.

ElNabawi concludes her article, in agreement with musician Omar Foda whom she also interviewed, by stating that the nationalistic music trend is concerning, as it inspires suspicion (a very potent political force, as shown by Mark LeVine and Maria Malmström [2019]) and incites hatred, often in relation to an imaginary enemy against which the military may present itself as the only protector. She writes: 'Looking at the histories of Nazism, Trotskyism, Zionism, and Communism, nationalism seems like a possible precursor to gruesome bottomless pits of religious or military fascism' (ElNabawi 2013).

Nationalism and gender politics, particularly those that relate to the militarized ideal of masculinities, are closely related, but their commonalities can sometimes be difficult to notice. This is mainly because 'the nation' is seen as beyond the realm of politics, or as larger than politics; this perception of the nation in turn hides the ideology or politics of the state. The same is true for the activities of the armed forces and their legitimacy. Military operations and campaigns are often portrayed as necessary and unavoidable because of the security situation, or the 'stability' of the nation, thus making it difficult to oppose them. This also means that there are connections between nationalism and gendered ideals, as the national project comes with obligations to serve it, which for men means to kill and put themselves at risk for 
the nation - something that is referred to by Paul Preciado as central to masculinity, and paralleled in the state's monopoly on violence: 'Within this system, masculinity is defined necro-politically (by men's right to inflict death), while femininity is defined bio-politically (by women's obligation to have children)' (Preciado 2018). This obligation is aided by constructions about 'male bravery' and 'courage', perpetuated through watani music and is aimed at making men believe that military service is somehow essential to their masculinity. This nationalist, military masculinity is placed against 'the threat', often constituted by a villain masculinity - terrorists or Islamists are common examples, although often the threat remains elusive and ambiguous. Yet it is always clear that the military is a competent guardian of the nation. The elusive threat plays a part in a 'securitization' process, which acts to legitimize militaristic masculinity and portray military men as 'heroes'. These heroic men, whether unnamed individuals or the military as an entity, are often central in watani music.

Many pro-military songs follow a style that is popular in its time, such as upbeat pop songs like Hosny's 'Motshakeren ya geshna' (Thank you our army) or the less known 'Fawadnak' (We authorized you) by Gharam and Hanin, which is more in the style of what is called mahraganat or electronic sha'bi, or the more complex 196o operetta 'al-Watan al-akbar', which is reminiscent of the militaristic communist songs of the Soviet Union, and differs greatly in style from contemporary nationalistic, pro-military songs.

Considering the political landscape in Egypt since the ousting of Morsi, marked by continued and even increasing repression against dissenting cultural actors, artists have a lot to gain by publicly supporting the new regime and its military backers and a lot to lose by publicly criticizing them. Gilman writes about the perils of being Tamer Hosny during the uprisings of 2011:

The government might not be able to stop him from singing entirely, but, since pop singers in Egypt generally earn their livelihood by performing private concerts booked by the wealthy elite for weddings and other such festivities, it would not be difficult for the authorities to apply a little judicious pressure here and there, and cut Tamer out of the industry. If he cannot perform at home and cannot travel abroad, then he no longer has a career at all.

GILMAN 2011 
While Hosny has been heavily criticized for allowing himself to become a puppet of the military regime, he is clearly not alone in this position, while other artists, such as Ramy Essam, have been forced to leave the country. Some artists even seem to compete in how long they have held negative opinions about the Muslim Brotherhood. For example, in a Tweet after the release of her song 'Mesh men baladna' (Not from our country), artist Angham (@angham) claimed that the song, which portrays the Muslim Brotherhood as enemies of the state and the military as the nation's guardian, was in fact written seventeen years earlier-thus, she emphasizes how long she has opposed the brotherhood (Angham 2013). Whether it is true or not, the song was released shortly after the military takeover in 2013, and the music video shows footage of alleged Muslim Brotherhood members and Morsi supporters committing acts of violence during the protests against the military, acts that legitimize the violent response of the military regime. ${ }^{10}$

Music, like most forms of art, can be used for or against specific ideologies, and in the case of watani music - whether in the form of pop operetta, classical operetta, sha'bi, shababi or any other style-it is used to promote the military, and support their consolidation of power. What has historically been a clear division 'between two forms of nationalism deploying the same nationalist discourse' (Frishkopf 2008: 49) has arguably become blurred. Frishkopf argues that the repressive, state-oriented nationalism will eventually clash with the popular nationalism associated with protest songs and folk music. However, I believe that in recent years, the impersonal nationalism of the state has been transformed through the appropriation of populist nationalism to form a state-sanctioned style of music existing between these two forms of patriotic nationalism. Because of this, there is a risk that the 'unavoidable clash between popular and state-oriented nationalism' (Frishkopf 2008: 49) actually can be avoided.

As previously delineated, the idea of military masculinity, and rugulat almasriyeen (Egyptians' manhood) represented through the armed forces, is closely tied to the military. The rugula of the army is often emphasized by pointing to feats of strength and the use of violence against enemies of the state. For example, see the music video of 'Teslam al-ayadi', which is filled with footage of the army in action, or see the first line of 'Set sa'at'. However, it is important to note that it is not the violence itself that is seen as a marker of the army's masculinity, but rather how and why they utilize it; namely, to protect the (imagined feminine) nation. ${ }^{11}$

10 The music video is available online: https://www.youtube.com/watch?v=8vDRx4oLA-U.

11 An example of the nation imagined as female/feminine can be seen in the statue Nahdet 
The differentiation between 'legitimate', masculine violence and illegitimate, cowardly violence, is presented in the music video of 'Mesh men baladna' (Not from our country), which shows footage of violence allegedly perpetrated by Muslim Brotherhood-aligned protestors in 2013. The combination of these images and the sentiment 'mesh men baladna' not only serves to defame the protestors, but also frames them as enemies of the state. This legitimizes the military's violence against them and portrays the military soldiers as heroes and saviors. Watani songs similarly construct soldiers as heroes willing to sacrifice their bodies to protect the symbolic 'body' of the nation. The opposition, by contrast, are strangers, villainous men who seek to destroy that body. The Egyptian nation is portrayed as threatened, and, therefore in need of protection against both external and internal forces. This legitimizes both militarization and policing and makes it difficult to oppose. This portrayal of the military as not only necessary, but also necessarily positive then becomes a matter of ideology. Furthermore, if the military is read as masculine, the same portrayal of necessity and positivity is true for the 'military masculine', which is defined as the guardian or protector of the feminine.

\section{$11 \quad$ Conclusion}

While there have been numerous studies on developments in Egyptian culture since 2011, almost none have taken into account the wave of watani music, a trend that is particularly noticeable since the ousting of Morsi in 2013. The few researchers that mention this phenomenon do so only in passing and tend to dismiss it as obvious propaganda for the military, and therefore as a trend that holds little or no potential to affect listeners (cf. Gilman 2014; LeVine 2015). My observations, however, suggest that, like oppositional music, it may still have an impact on people and may inspire them to political action in support of the military. This is a particularly important point, as watani songs such as 'Teslam al-ayadi' enjoys widespread popularity. The influence of watani songs is also confirmed by Gilman, who writes about 'Teslam al-ayadi': 'The video clip seems to have garnered more positive and more numerous views on YouTube than had its (even more) mediocre predecessors' (Gilman 2014: 206), despite it being military propaganda.

Misr, which stands outside Cairo University, and also appears on Egyptian bills. See also Baron 2005. 
The idea of the nation, around which these songs often explicitly revolve, and masculinity, around which they often implicitly revolve, have many common focal points. Yet, as an abstract concept, the nation is often thought to transcend the political, and because the military is seen to serve the nation (rather than to serve politics), its political nature is somewhat hidden. With reference to 'stability' and 'security', the military legitimizes its presence in civil society, and then maintains this stabilizing image through cultural productions that extol the activity of the military (and in some cases portray the potential dangers of its enemies). Furthermore, there are, as noted in this paper, connections between nationalism and gender constructions; the national project obliges men to offer their bodies to the military cause. This obligation is aided by constructions about 'male bravery' and 'courage' designed to make men feel that military service is somehow essential to their masculinity. Watani music, whether commissioned or not, fits well with this mythology of military men. It forms an ideological undercurrent, supporting the narrative of the necessity of the nation's military men who bravely safeguard the nation against its enemies, within and outside its borders.

There are many aspects of watani music that require detailed study, both in terms of textual analysis, looking at the messages and lyrics in songs such as 'Teslam al-ayadi', but also in terms of the producers: what do they hope to achieve with their songs and what stimulated them to write and perform them? More importantly, there is still vast room for ethnographic study on the reception of watani songs and the influence of militaristic-patriotic messages. Taking into account the popularity of watani songs since the ousting of Morsi in 2013, and the current political reality of Egyptian society, now more than ever it is necessary to understand the presence of Egypt's military, not only on the streets, but also in the cultural products of popular artists.

\section{References}

Abdel Kouddous, Sharif (2014). Egypt's 1984. Sada. Accessed 7 Oct. 2020: https://carne gieendowment.org/sada/57051. 28 Oct. 2014.

Abdelmoez, Joel W. (2018). Muscles, Moustaches and Machismo: Narratives of Masculinity by Egyptian English-Language Media Professionals and Media Audiences. Masculinities: A Journal of Identity and Culture 9-10: 197-225. Accessed 7 Oct. 2020: http://www.masculinitiesjournal.org/en-us/makele/muscles--moustaches-and -machismo-narratives-of-masculinity-by-egyptian-englishlanguage-media -professionals-and-media-audiences-/238/pdf.

Abul-Magd, Zeinab (2013). The Egyptian Military in Politics and the Economy: Recent 
History and Current Transition Status. CMI Insight 2: 1-6. Accessed 7 Oct. 2020: https://www.cmi.no/publications/4935-the-egyptian-military-in-politics-and-the -economy.

albawaba online (2013). One Egypt, One Song, One Love: Stars Dedicate Their Music to Egypt. Accessed 7 Oct. 2020: http://www.albawaba.com/entertainment/song -patriotic-egypt-music-516203. 27 Aug. 2013.

Amar, Paul (2011). Middle East Masculinities: Discourses of 'Men in Crisis', Industries of Gender in Revolution. Journal of Middle East Women's Studies 7 (3): 36-70, https:// doi.org/10.2979/jmiddeastwomstud.7·3.36.

Amar, Paul (2013). The Security Archipelago: Human-Security States, Sexuality Politics, and the End of Neoliberalism. Durham: Duke University Press.

Angham [@angham] (2013). Twitter post, 22 Aug. 2013, 11:21 pm, https://twitter.com/ Angham/status/370657007789170688.

Armbrust, Walter (2000). Introduction. In Walter Armbrust (ed.), Mass Mediations: New Approaches to Popular Culture in the Middle East and Beyond, pp. 1-31. Berkeley: University of California Press.

Baron, Beth (2005). Egypt as a Woman: Nationalism, Gender, and Politics. Berkeley: University of California Press.

Boyd, Douglas A. (1975). Development of Egypt's Radio: 'Voice of the Arabs' under Nasser. Journalism Quarterly 53 (4): 645-653, https://doi.org/10.1177/1077699075052 00406 .

Brown, Nathan J., Emad El-Din Shahin and Joshua Stacher (2013). Egypt. In Michele Penner Angrist (ed.), Politics and Society in the Contemporary Middle East, pp. 217249. Boulder: Lynne Rienner Publishers.

El Hamamsy, Walid and Mounira Soliman (2013). Popular Culture in the Middle East and North Africa: A Postcolonial Outlook. New York: Routledge.

ElNabawi, Maha (2013). Egypt's Musical Nationalism, and a Little George Orwell. Accessed 11 Feb. 2016: https://www.madamasr.com/en/2013/o8/20/feature/culture/ egypts-musical-nationalism-and-a-little-george-orwell/. 20 Aug. 2013.

Enloe, Cynthia (2013). Masculinities, Policing, Women and International Politics of Sexual Harassment. International Journal of Feminist Politics 13 (3): 77-81, https:// doi.org/10.1080/14616742.2012.742681.

Frishkopf, Michael (2008). Nationalism, Nationalization, and the Egyptian Music Industry: Muhammad Fawzy, Misrphon, and Sawt al-Qahira (SonoCairo). Asian Music 39 (2): 28-58, https://doi.org/10.1353/amu.o.ooo9.

Frishkopf, Michael (2010). Introduction. In Michael Frishkopf (ed.), Music and Media in the Arab World, pp. 1-64. Cairo: American University in Cairo Press.

Ghannam, Farha (2013). Live and Die Like a Man: Gender Dynamic in Urban Egypt. Palo Alto: Stanford University Press.

Ghoussoub, Mai, and Emma Sinclair-Webb (2000). Imagined Masculinities: Male Identity and Culture in the Modern Middle East. London: Saqi Books. 
Gilman, Daniel J. (2011). Why Tamer Hosny Won’t Go Away. Jadaliyya. Accessed 7 Oct. 2020: https://www.jadaliyya.com/Details/23905/Why-Tamer-Hosny-Won\%6ot-Go -Away. 19 April 2011.

Gilman, Daniel J. (2014). Cairo Pop: Youth Music in Contemporary Egypt. Minneapolis: University of Minnesota Press.

Gordon, Joel, and Heba Arafa (2014). 'Stuck with Him': Bassem Youssef and the Egyptian Revolution's Last Laugh. Review of Middle East Studies 48 (1-2):34-43.

Grippo, James R. (2010). What's Not on Egyptian Television and Radio! Locating the 'Popular' in Egyptian Sha'bi. In Michael Frishkopf (ed.), Music and Media in the Arab World, pp. 137-162. Cairo: American University in Cairo Press.

Grove, Nicole Sunday (2015). The Cartographic Ambiguities of HarassMap: Crowdmapping Security and Sexual Violence in Egypt. Security Dialogue 46 (4): 345-364, https://doi.org/10.1177/og67010615583039.

Higate, Paul (ed.) (2003). Military Masculinities: Identity and the State. Westport: Praeger.

Inhorn, Marcia (2012). The New Arab Man: Emergent Masculinities, Technologies, and Islam in the Middle East. Princeton: Princeton University Press.

Kabesh, Amal Treacher (2015). Political Upheaval in Egypt: Disavowing Troubling States of Mind. Psychoanalysis, Culture \& Society 20: 343-358, https://doi.org/10.1057/pcs .2015 .61 .

Khairy, Amina (2014). Common Sense in Egypt: Teslam el-Ayadi. Egypt Independent. Accessed 18 Nov. 2020: https://egyptindependent.com/common-sense-egypt -teslam-el-ayadi/. 22 March 2014.

Kraidy, Marwan (2006). Reality Television and Politics in the Arab World: Preliminary Observations. Transnational Broadcasting Studies. Accessed 7 Oct. 2020: https:// repository.upenn.edu/asc_papers/303. 1 Jan. 2006.

LeVine, Mark, and Maria Frederika Malmström (2019). Understanding the Materiality of Suspicion: Affective Politics in MENA Cities. In Mansour Nasasra and Haim Yacobi (eds.), Routledge Handbook on Middle East Cities, pp. 136-152. London: Routledge.

LeVine, Mark (2015). When Art Is the Weapon: Culture and Resistance Confronting Violence in the Post-Uprisings Arab World. Religions 6 (4):1277-1313, https://doi.org/ 10.339o/rel6o41277.

McDonald, David A. (2013). My Voice Is My Weapon: Music, Nationalism and the Poetics of Palestinian Resistance. Durham, NC: Duke University Press.

Morsy, Ahmed (2014). The Military Crowds Out Civilian Business in Egypt. Carnegie Endowement for International Peace. Accessed 7 Oct. 2020: http://carnegieendow ment.org/2014/o6/24/military-crowds-out-civilian-business-in-egypt. 24 June 2014.

Naguib, Nefissa (2015). Nurturing Masculinities: Men, Food, and Family in Contemporary Egypt. Austin: University of Texas Press.

Nassar, Zein (2010). A History of Music and Singing on Egyptian Radio and Television. 
In Michael Frishkopf (ed.), Music and Media in the Arab World, pp. 67-76. Cairo: American University in Cairo Press.

Preciado, Paul (2018). Letter from a Transman to the Old Sexual Regime. Texte Zur Kunst. Accessed 8 Oct. 2020: https://www.textezurkunst.de/articles/letter-trans -man-old-sexual-regime-paul-b-preciado/. 22 Jan. 2018.

Rizzo, Helen (ed.) (2014). Masculinities in Egypt and the Arab World: Historical, Literary, and Social Science Perspectives. Cairo: American University in Cairo Press.

Sayigh, Yezid (2019). Owners of the Republic: An Anatomy of Egypt's Military Economy. Civil-Military Relations of the Arab States of the Carnegie Middle East Center. Accessed 18 Nov. 2020. https://carnegie-mec.org/2019/11/18/owners-of-republic -anatomy-of-egypt-s-military-economy-pub-80325. 18 Nov. 2019.

Sprengel, Darci (2019). 'More Powerful than Politics': Affective Magic in the DIY Music Activism after Egypt's 2011 Revolution. Popular Music 38 (1): 54-72, https://doi.org/ 10.1017/So261143018000715.

Swedenburg, Ted (2012). Egypt's Music of Protest: From Sayyid Darwish to DJ Haha. Middle East Report 265: 39-43.

Valassopoulos, Anastasia, and Dalia Said Mostafa (2014). Popular Protest Music and the 2011 Egyptian Revolution. Popular Music and Society 37 (5): 638-659, https://doi.org/ 10.108o/03007766.2014.910905.

Van Eynde, Koen (2015). Men in the Picture: Representations of Men and Masculinities in Egyptian Cinema since 1952. PhD dissertation, Katholieke Universiteit Leuven. 